\title{
The International Crime of Persecution ${ }^{1}$
}

O Crime Internacional de Perseguição

Joshua Zatcoff ${ }^{2}$

\section{RESUMO}

Esse artigo procura esboçar a recente história do crime internacional de perseguição, como delineado no Estatuto Romano, através da causa estabelecida pelas cortes internacionais nos últimos anos. Revela-se aqui a amplitude de ambas as possibilidades da acusação do tipo perseguição que ironicamente acentua e atenua a acusação.

Palavras-Chave: Direito Internacional; Crime de Perseguição.

\section{ABSTRACT}

This paper will outline the history and recent development of the international crime of persecution, as set forth in the Rome Statute, through the case law as established by the international courts over the past several years.

Keywords: International Law; Crime of Persecution.

\section{An Introduction to the Crime of Persecution and a Summary of Its Current Status}

The first part of the essay will provide an introduction to the crime of persecution, its legal and historical origins, and an overview of the current modes of thought regarding the issue as well as the contemporary patterns of analysis for adjudicating this crime, and the emerging trends surrounding it. The still-evolving legal principles which inform this compendium will then be demonstrated via the facts and rulings of four different cases of significance, one each for the years 2008, 2009, 2010, and 2011.

\footnotetext{
${ }^{1}$ Artigo recebido em 24 de maio de 2013 e aprovado para publicação em 16 de outubro de 2013.

2 Doutor em Direito Internacional pela New England School of Law e Bacharel em Ciência Política pela Brandeis University, Massachusetts, Estados Unidos. 
The crime of persecution is a particularly interesting international crime with regard to its constitution due to the potentially universal application it has to every other crime against humanity; in essence, anything from "torture" to "enslavement" has the possibility of also being a crime of persecution when certain factors are met (Dictionary of Gross Human Rights Violations; Persecution, 2013). In this respect, the nature of the charge allows for a broad and far-reaching external impact in the international criminal arena. Its internal definition-and meeting it-is more nuanced, however. Originally, though, even the bases of a charge of persecution were confined too much narrower grounds than we see today. The Nuremberg Trials at the end of World War II delineated "political, racial or religious" reasons as the sole categories of motivation which could be prosecuted as persecution (Id., 2013).

These must have been connected to or behind another crime within the jurisdiction of the International Military Tribunal which convened at the conclusion of the conflict (Id., 2013). The prime example given by that Court was the "complete exclusion of Jews from German life prior to the start of World War II" (CERONE, 2005). This included the "the espousal of hatred toward Jews, discriminatory arrest and detention, the looting of Jewish businesses [....] the confiscation of assets, the burning and demolition of synagogues, the creation of ghettos, restriction of freedom of movement, the imposition of collective fine, and the organization of pogroms" (Id., 2005).

The time-frame in which these were considered, however, mandated an adherence to an archaic order of international relations which stressed that only inter-state crimes could be punished by outside legal bodies; this was premised on the concept of "nonintervention" into purely "domestic" affairs (Id., 2005). Thus, the Nazi targeting of Jews because of their race and/or religion were of a type that ordinarily would meet the Nuremberg construct of persecution. Yet the fact that the above listed were ante-bellum actions which took place mostly inside state borders and not between them rendered them immune to prosecution, as determined by a rather hesitant Nuremberg Court (Id., 2005).

In the years following the Nuremberg Trials, and especially over the past two decades, the arm of the crime of persecution rapidly lengthened, while its composition became more closely defined. The International Criminal Tribunal for Rwanda structured 
the crime into two concrete tiers, with quasi-distinct qualifying elements. These are: (1) that the specific act in question must have been persecutory owed to discrimination along the old Nuremberg lines of politics, race, or religion; and (2) that the overall assault encompassing the specific act was also discriminatory (Id., 2005). The latter tier, however, adds both "nationality" and "ethnicity" to the traditional "politics, race or religion" as sufficiently insidious impetus toward receiving an ultimate classification as persecution (Id., 2005).

Taken together, if the first tier is catalyzed by or directed at one of the three given elements, and the second tier by any of the five, the International Criminal Tribunal for Rwanda would designate the act to be a crime of persecution (Id., 2005). The successive jurisprudence of the International Criminal Tribunal for the former Yugoslavia, on the other hand, has laid out a four part test for persecution; it has said that for an act to be called persecution, it must be: (1) an obvious or blatant denial, (2) for discriminatory reasons, (3) of a fundamental right under customary international law or treaty, and/or (4) reaching the same gravity as other crimes against humanity prohibited by Article 5 of the Statute (Id., 2005).

Another legal principle derived from the Tribunals since their inception is the renewed emphasis on the individual, both as the persecutor and the persecuted. This means that "crimes against humanity need not be supported by some larger government policy" for them to still be criminal - i.e. non-state actors could be legitimate offenders; and, according to the International Criminal Tribunal for the former Yugoslavia, a single person "can be the victim of persecution, as long at the contextual elements for crimes against humanity have otherwise been met" (Dictionary of Gross Human Rights Violations; Persecution, 2013).

Indeed, the foundational laws pertaining to the crime of persecution have been inscribed in Article 7 of the Rome Statute, which governs the International Criminal Court, and Article 5 from the International Criminal Tribunal for the Former Yugoslavia (Id., 2013). The relevant lines from the Rome Statute note persecution as "the intentional and severe deprivation of fundamental rights contrary to international law by reason of the identity of the group or collectivity" (Id., 2013). The Trial Chamber from the International 
Criminal Tribunal for the former Yugoslavia describes actions as being persecution "those of a physical, economic or judicial character, which prevent a person from exercising fundamental rights" (Hague Justice, 2013). An ongoing armed conflict is not prescribed by the statute as necessary for persecution to be present, as the actions may occur during "war or peace" (Dictionary of Gross Human Rights Violations; Persecution, 2013).

What must be present is either a "widespread or systematic attack" (Id., 2013). Moreover, both the International Criminal Court and the International Criminal Tribunal for the Former Yugoslavia have inherent within their legal codes an enlargement of the idea of who is protected and also what they are protected from. Beyond all of the aforementioned groups, "gender" as well as "culture" have now been detailed for protection by the tribunals (Id., 2013); and, after concluding with "gender" as a legally safeguarded attribute of a person for the first time, the Rome Statute goes even further, mentioning "other grounds that are universally recognized as impermissible [for persecution] under international law" (Rome Statute Article 7, 2013). Meanwhile, the Rome Statute says that the type of persecution itself "may also include other acts not included under the listed crimes against humanity" (Dictionary of Gross Human Rights Violations; Persecution, 2013).

This would happen if they nevertheless could be deemed an "intentional and severe deprivation of fundamental rights contrary to international law by reason of the identity of the group or collectivity," (Rome Statute Article 7, 2013) as stated previously. The International Criminal Tribunal for the Former Yugoslavia has enunciated an actual test for determining if those acts which fall outside the listed crimes against humanity still meet the level of being labeled persecution; called the "same level of gravity" assessment, it holds that "acts of a comparable gravity constitute persecution" (Dictionary of Gross Human Rights Violations; Persecution, 2013). This evaluation is made cumulatively; hence, only the effect of the actions on the aggregate matters, even if these are non-criminal (Id., 2013) Analyzed in sum, they "may be sufficient to reach the same level of gravity as the enumerated acts" (Id., 2013).

The increasing prevalence of the crime of persecution on the international legal stage might be partly a result of prosecutorial advantages intrinsic to this charge: 
"prosecuting for persecution rather than for genocide has a real advantage, as it properly reflects the situation on the ground, and recognises (sic) the full criminality of serious violations of social, economic and cultural rights," such as those which instigated the horrific violence and strife in Darfur (Hague Justice, 2013). "The crime of persecution is not of interest only because its specific intent is significantly easier to prove then (sic) that of genocide, but also because its constituent elements are broader and less fixed than those of genocide" (Id., 2013). Perhaps the best way to understand how international law has arrived at the position just explained is to review several of the cases which produced and configured this outcome.

\section{The Crime of Persecution and Mens Rea}

In 2008, the International Criminal Tribunal for the Former Yugoslavia settled the case of Prosecutor v. Milan Martic Case no. IT-95-11-1. The facts germane to the situation arose between August 1991 and December 1995 (International Criminal Tribunal for the former Yugoslavia - ICTY; Trial Judgment, paragraphs 445-446, 2013). After his 143 day trial, Milan Martic was found by the Trial Chamber through the production of 45 witnesses and 901 exhibits to have participated in a "joint criminal enterprise," which had as its common objective the ethnic cleansing of a certain territory by forcibly removing all of its non-Serb inhabitants (Id., 2013). The crime of persecution was count one against Mr. Martic (Id., paragraph 447, 2013). Initially, Mr. Martic was found not-guilty beyond a reasonable doubt of persecution in its most direct form (Id., 2013).

This was because, while Mr. Martic had in fact ordered the shelling of Croation cities, the Trial Chamber could not find enough evidence that Mr. Martic had intended to commit these actions as discrimination on the basis of ethnicity (Id., 2013). "Rather, the evidence shows that Milan Martic intended to shell the city of Zagreb in order to retaliate on Croatia and to stop further Croatian attacks" (Id., 2013). This marks a very important distinction drawn by the Chamber: military tactics are not forbidden outright, whatever their severity; it is the mens rea of the action, not the actus reus, which determines what amounts to persecution. 
As the Court put it, "while an attack on a city, such as in this case, is without doubt grave, the Trial Chamber cannot find that it establishes in and of itself that it was carried out with the requisite intent" (Id., 2013). The Trial Chamber thus proceeded to convict Mr. Martic under a more basic form of "joint criminal enterprise," finding that Mr. Martic "provided substantive financial, logistical and military support" for ethnic cleansing of nonSerbs, and by "fuelling an atmosphere of insecurity and fear through public statements" against non-Serb residents (Id., paragraphs 445-446, 2013). The circuitous manner in which the Court nonetheless managed to convict Mr. Martic displays many of the summarized points from Part I, such as the broadness of the crime of persecution, and the linked prosecutorial advantages this promotes.

The Court went on to say, "the Trial Chamber recalls that Milan Martic was aware that the non-Serb population was being subjected to widespread and systematic crimes, including killings, unlawful detentions, beating while detained, and crimes against property, as a result of [a] coercive atmosphere (Id., paragraph 454, 2013). The Trial Chamber "considere[d] that this atmosphere was created and sustained by the actions of Milan Martic and other members of the [joint criminal enterprise]." The Trial Chamber therefore "[found] that the crimes which have been found to be outside the common purpose were foreseeable to Milan Martic" (Id., 2013). "Furthermore," the Court continued, "the evidence includes only scarce reference to Milan Martic acting to take measures to prevent or punish such crimes," and "despite the overwhelming evidence of the scale and gravity of the crimes being committed against the non-Serb population, Milan Martic persisted in the common purpose of the [joint criminal enterprise]" (Id., 2013).

Based upon this syllogism by the Court, it concluded that "[t]hus, the Trial Chamber considers it proven beyond reasonable doubt that Milan Martic willingly took the risk that the crimes which have been found to be outside the common purpose might be perpetrated" (Id., 2013). Accordingly, the Court convicted Mr. Martic of Count One of persecution by showing that guilt of this particular crime can be construed not just from what a person intended, per se, or even what he did, but equally as much by what he reasonably should have or did know and, as a figure of authority, did not do. In the Court's own language, Mr. Martic was complicit for negligent lack of foresight or corrective course 
(Id., 2013). This added to the depth of the formulation of the crime of persecution as a whole.

\section{The Crime of Persecution and Actus Reus/Property Destruction}

In 2009 the same court handled the case of Prosecutor v. Milutinović et al., Judgement, IT-05-87-T, 26. Unlike the preceding case, the Trial Chamber in Milutinovic did deal with actus reus, but in the crucial and limited context of property rights as a means of persecution. Usually, property crimes "are not considered to be of sufficient gravity to constitute persecution, unless they threaten the livelihood of the victim population. Nonetheless, several ICTY judgments have found the destruction of property can amount to persecution when committed in conjunction with other inhumane acts" (Dictionary of Gross Human Rights Violations; Persecution, 2013). Milutinovic was one of these referred to judgments. In it, the Trial Chamber held that the actus reus for property crimes indicating persecution is threefold: (a) the property has been destroyed or significantly damaged; (b) the property was not used for military purposes at the time of the acts; and (c) the destruction or damage is the result of an act directed against it (International Criminal Court; Prosecutor v. Milutinović et al., Judgement, IT-05-87-T, 26. paragraphs 206$207,2009)$.

This ruling implicates the "equal gravity" test discussed in Part I: to fulfill the requirement of other crimes against humanity as illustrated in Article 5 of the Statute for the International Criminal Tribunal for the former Yugoslavia, the severity of the crime is nearly everything. This stands in stark opposition to the Martic case. Here, then, the "cumulative" test is also at play: when the impact of the property loss is almost absolute,

causing the deprivation of a way of life and the obliteration of vital, sustaining land, materials, and edifices (especially housing) to the owners, the Court ruled that the totality can be seen as a crime of persecution, so long as the property was not a launch pad for military operations or planning and its subsequent displacement of civilians was not accidental (Id., 2009). 
The Court said that "indiscriminate looting of homes, buildings, businesses, civilian personal property and livestock can be an act of the crime of persecution" (Id., 2009). This aids us, too, in the understanding of how the crime of persecution can give focus to "the full criminality of serious violations of social, economic and cultural rights" it was credited with in Part I. This will be contemplated supplementally in the next section.

\section{The Subsumption of Other Crimes Against Humanity Into the Crime of Persecution}

In 2010, the Extraordinary Chambers in the Courts of Cambodia oversaw the case of Prosecutors v. Kaing Guek Eav alias Duch, Case No. 001/18-07-2007/ECCC/TC, concerning the chairman of an interrogation facility for the Khmer Rouge. Mr. Kaing Guek Eav, also known as "Duch," was charged with planning, instigating, ordering, committing, or

aiding and abetting crimes against humanity, grave breaches of the Geneva Conventions of 1949, and national crimes of premeditated murder and torture (Prosecutors v. Kaing uek Eav alias Duch, paragraph 11, 2010). An allegation of rape was made on behalf of a female detainee of the interrogation center who was vaginally penetrated by an employee of the detention facility with a stick (Id., 2010). The Trial Chamber, however, chose to call this crime "torture," as it "was an egregious component of the prolonged and brutal torture inflicted upon the victim prior to her execution" (Journal of International Human Rights, p. $351,2011)$.

Afterward, the Trial Chamber decided that "the findings of torture were subsumed within the crime against humanity of persecution on political grounds" (Id., 2011). This meant that "the evidence of rape was first collapsed into the crime against humanity of torture, and then torture was collapsed into the crime against humanity of persecution" (Id., p.352, 2011). This was "despite the fact that the Chamber recognized that the facts met the legal elements of both rape and torture" (Id., 2011). This helps to unveil the double-edged sword which a crime as broad as persecution can be-it casts a wide net which can sometimes run the risk of transplanting and even undermining other charges instead of working in tandem with them if not handled carefully; "the Co-prosecutors argued that the Trial Chamber erred by failing to convict Dutch cumulatively for the 
distinct crimes against humanity of rape and torture, and again by subsuming various prohibited acts, including rape, within the crime against humanity of persecution on political grounds" (Id., 2011).

This might be interpreted as a susceptibility to the judicial convenience which a charge like persecution is apt to bring. "The Co-Prosecutors not only argued that rape and torture, and rape and persecution, contain materially distinct elements not found in the other, they also argued that the Trial Chambers did not correctly apply existing case law on cumulative convictions" (Id., 2011). The Co-Prosecutors maintained their advocacy in favor of restoring the separation of the charges on policy rationale: "Co-Prosecutors posited that there are clear societal interests in convicting the accused with rape, torture, and persecution in order to have the judgment paint a complete picture of Duch's criminality." In other words, this case reveals that the breadth of a charge like persecution ironically covers the gamut of both ensuring and attenuating the fullness of a criminal prosecution.

\section{The Crime of Persecution, Gender, and the Future}

Finally, earlier this year, the International Criminal Court looked ready to explore gender-based persecution as a crime against humanity for the first time in the case of Prosecutor v. Mbarushimana, Case No. ICC-01/04-01/10-2-tEN (Id., p. 330, 2011). "The Rome Statute was the first statute of an international or internationalized criminal tribunal to include "gender" within the list of prohibited persecutory grounds" (Id., 2011). The case, therefore, was supposed to "break new grounds in terms of outlining the content of gender based persecution, and in interpreting the term "gender" as it is defined in the Rome Statute" (Id., 2011). Unfortunately for those interested in the instant crime and the larger subject, this legal enlightenment will be forced to wait. Mr. Mbarushimana, a Hutu rebel leader, was accused of murder and rape in the Democratic Republic of Congo (BBC News Africa, 2011).

He denied ordering his fighters to kill and rape civilians in 2009, and on December 16, 2011, "the judges at the ICC's pre-trial chamber declined to confirm the charges against Mr. Mbarushimana, 47, by a majority decision" (Id., 2011). The International Criminal Court 
judges "ordered the release of Callixte Mbarushimana because of a lack of evidence to back up the charges" (Id., 2011). The judges said "there was not sufficient evidence to establish substantial grounds to believe that the Rwandan rebel could be held criminally responsible" (Id., 2011).

This points to a future where the crimes adjudicated under the charge of persecution continue to transform throughout the international legal system, with areas not yet settled confronted, and issues already encountered increasingly clarified. It is a reminder to all that the delivery of justice without national boundaries remains a notion of novelty-yet to be finished.

\section{Referências Bibliográficas}

BBC News Africa. ICC dismiss Rwanda rebel Callixte Mbarushimana charges. Available at: http://www.bbc.co.uk/news/world-africa-16227154. Access: 12/16/2011.

Cerone, John. Persecution. In. Encyclopedia of Genocide and Crimes against Humanity. $1^{\text {st }}$ Ed: Thomson and Gale and Shelton Macmillan Reference USA, $1^{\text {st }}$ Ed. 2005.

HAGUE JUSTICE PORTAL. Available at:

http://www.haguejusticeportal.net/index.php?id=10761. Access: 09/15/2013.

International Criminal Court. Prosecutor v. Ahmad Muhammad Harun ("Ahmad Harun") and Ali Muhammad Ali Abd-Al-Rahman ("Ali Kushayb"), Warrant of Arrest for Ali Kushayb, Case No. ICC-02/05-01/07, 27 April 2007, Count Nos. 1, 10, 21 and 39. Available at: http://www.haguejusticeportal.net/index.php?id=8221. Access: $06 / 17 / 2009$.

International Criminal Tribunal for the former Yugoslavia - ICTY. Trial Judgment, paragraphs 445-446.). Prosecutors v. Kaing Guek Eav alias Duch, Case No. 001/1807-2007/ECCC/TC, Judgement (July 26, 2010). Avaible at: http://www.icty.org/case/martic/4. Access: 08/15/2013.

Osterveld, Valerie. Atrocity Crimes Litigation Year-in- Review (2010): A Gender Perspective , 9 Nw. J. InT'L Hum. RTs. 325 (p.351-353, 2011). Available at: 
http://scholarlycommons.law.northwestern.edu/njihr/vol9/iss3/3.

Access: $08 / 15 / 2013$.

Dictionary of Gross Human Rights Violations. Shared Humanity, 2007. Avaible at: http://www.sharedhumanity.org/LibraryArticle.php?heading=Persecution, $\% 20$ the $\%$ 20Crime\%20against\%20Humanity\%20of. Access: 11/10/2011.

Journal of International Human Rights. Northwestern Law University. Avaible at: http://www.law.northwestern.edu/journals/jihr/v9/n3/5/Oosterveld.pdf. Access: $08 / 15 / 2013$.

Rome Statute Article 7. Shared Humanity Organization. Avaible at: www.sharedhumanity.org/Documentation.php. Access: 11/10/2011. 